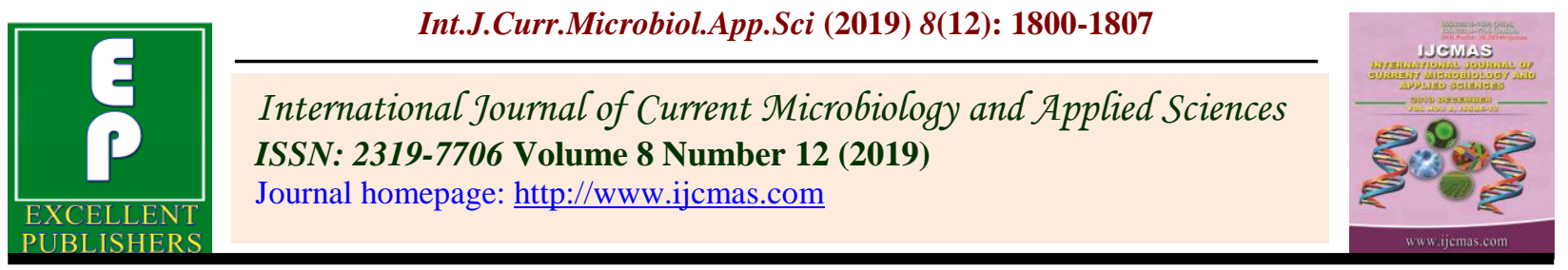

Original Research Article

https://doi.org/10.20546/ijcmas.2019.812.216

\title{
Estimating Profile of the Beneficiaries of Mahatma Gandhi National Rural Employment Guarantee Act
}

\author{
V. G. Dhulgand ${ }^{1 *}$ and R. P. Kadam ${ }^{2}$ \\ Department of Extension Education, Vasantrao Naik Marathwada Krishi Vidyapeeth \\ (VNMKV), Parbhani (M. S.), India \\ *Corresponding author
}

\begin{tabular}{|c|}
\hline Keywords \\
\hline $\begin{array}{l}\text { Profile analysis, } \\
\text { MGNREGA } \\
\text { beneficiaries }\end{array}$ \\
\hline Article Info \\
\hline $\begin{array}{l}\text { Accepted: } \\
15 \text { November } 2019 \\
\text { Available Online: } \\
10 \text { December } 2019\end{array}$ \\
\hline
\end{tabular}

A B S T R A C T

The present study was conducted purposively in Aurangabad, Nanded, Beed and Jalna district of the Marathwada region of Maharashtra state during the year 2017-2018. From this four districts eight tahsils were selected purposively. From each selected taluka two villages were selected purposively for the study. Fifteen (15) beneficiaries of MGNREGA were selected randomly from each selected villages. Thus comprising total 240 beneficiaries were selected from Marathwada region for research study. For estimating profile of the beneficiaries of Mahatma Gandhi National Rural Employment Guarantee Act. It was found that, majority (52.08\%) of the MGNREGA beneficiaries were middle aged, 28.75 per cent educated up to primary school level, $(40.84 \%)$ were found lower category, more than two third $(66.25 \%)$ of them having medium family size and 34.16 per cent of them having small size of land holding. It was observed that, more than half $(56.67 \%)$ of them having farming as main occupation, majority $(53.75 \%)$ of them having medium annual income, 57.09 per cent were found joint family, nearly half $(49.17 \%)$ of them having medium social participation, less than half $(46.66 \%)$ of them having medium source of information, 59.58 per cent of them having medium level of extension contact and 45.41 per cent of them having medium level of economic motivation.

\section{Introduction}

Poverty and unemployment are the twin problem faced by the developing countries. According to the planning commission of India nearly $29.8 \%$ population is Below Poverty Line (BPL). Policy makers in India have realized the need for generating employment opportunities on large scale to bring the teeming millions of population above poverty line (APL). While the labour force in India is increasing in numbers at every year. Majority of population (72.22 per cent) live in rural areas and many of them suffer owing to seasonal unemployment, under employment and disguised unemployment. (Source: Planning Commission). In India, GDP and Unemployment rates are going hand 
in hand, causing fret for any democratic society. Unemployment and poverty are strongly related and hinder the economic growth and development of the country.

In India, these two problems are severe in rural areas, leaving it outside the growth path. Thus, Government of India aiming at balanced growth and to overcome above mentioned weaknesses of past employment programmes, passed National Rural Employment Guarantee Act (NREGA) in 25 August 2005 in order to empower the rural labourers with right to get employment of 100 days per year per household during off-season. In accordance, National Rural Employment Guarantee Act has been launched in Anantapur district of Andhra Pradesh on $2^{\text {nd }}$ February, 2006, with effect from $1^{\text {st }}$ April 2006 in 200 drought prone and backward districts in India. This was extended to additional 130 districts in the financial year 2007-2008.

The NREGA coverage has been expanded from 330 districts to 619 districts of India beginning April, 2008. In Maharashtra the NREGA was implemented during the 2006 in 12 districts (Dhule, Nandurbar, Ahemednagar, Aurangabad, Hingoli, Nanded, Amravati, Gadchiroli, Yavatmal, Bhandara, Gondhiya and Chjandrapur) of Maharashtra state.

Thus NREGA covered that entire country with the exception of districts that have a hundred percent urban population. This programme has been formulated by merging early formulated programmes such as Sampoorna Gramin Rozgar Yojana (SGRY) of 2001 and National Food for Work Programme (NFFWP) of 2004.

Again the Government of India on $2^{\text {nd }}$ October, 2009 renamed its flagship rural job guarantee programme- National Rural Employment Guarantee Act (NREGA) as Mahatma Gandhi National Rural Employment Guarantee Act (MGNREGA).

\section{Materials and Methods}

The present study was conducted purposively in Aurangabad, Nanded, Beed and Jalna district of the Marathwada region of Maharashtra state during the year 2017-2018. Selected district eight tahsils were selected purposively. From each selected taluka two villages were selected purposively for the study. Fifteen (15) beneficiaries of MGNREGA were selected randomly from each selected villages. Thus comprising total 240 beneficiaries were selected from Marathwada region for research study. For estimating profile of the beneficiaries of Mahatma Gandhi National Rural Employment Guarantee Act. Ex-post facto research design was adopted in this study. The data were collected with the help of pretested interview schedule. The statistical methods and tests such as frequency, percentage, mean and standard deviation were used for the analysis of data.

Estimating profile of the beneficiaries of Mahatma Gandhi National Rural Employment Guarantee Act.

\section{Results and Discussion}

\section{Personal and socio-economic characteristics of the beneficiaries of Mahatma Gandhi}

\section{National rural employment guarantee act}

\section{Age}

It was observed from Table 1 that, more than half $(52.08 \%)$ of the MGNREGA beneficiaries were belongs from middle age group i.e. (36 to 50 years). Whereas, 35.00 per cent of MGNREGA beneficiaries were from young age group i.e. (up to 35 years) and remaining 12.92 per cent of MGNREGA beneficiaries were old age group i.e. (51and above years). It was observed from below table that, most of 
the MGNREGA beneficiaries belong to middle age category i.e. 36 to 50 years.

\section{Education}

It was revealed from Table 2 that, $(28.75 \%)$ of the MGNREGA beneficiaries were educated up to primary school level, followed by 21.25 per cent of them were educated up to can read and write, while 20.41 per cent of them middle school, 15.84 per cent of them can read only, 8.75 per cent of them were illiterate, 5.00 per cent of them were educated up to high level education.

Whereas none of them were educated up to college level education. It was observed from below table that, most of the MGNREGA beneficiaries were educated up to primary school education i.e. (1st to 4 th standard).

\section{Category}

It is clear from Table 3 that, 40.84 per cent of beneficiaries of MGNREGA belonging to lower caste group i.e. (SC, ST and NT) followed by $(31.25 \%)$ middle caste i.e. (OBC and Muslim) and (27.91\%) of beneficiaries of MGNREGA from upper cast i.e. (Open). It was observed from above table that, most of the MGNREGA beneficiaries were having lower cast (SC, ST and NT).

\section{Family size}

The data furnished in Table 4 indicated that, more than half $(66.25 \%)$ of beneficiaries were belongs from medium family size i.e. 5 to 6 members, followed by 17.92 per cent and 15.83 per cent of them were with the big i.e. more than 7 members and small size i.e. less than 4 members of family, respectively. It was observed from below table that, most of the MGNREGA beneficiaries were having medium family size i.e. 5 to 6 members.

\section{Land holding}

It was observed from Table 5 that, 34.16 per cent of MGNREGA beneficiaries were having small size of land holding i.e. 1.01 to 2.00 ha, followed by 25.00 per cent of them had semimedium size of land holding i.e. 2.01 to 4.00 ha.

Whereas, 23.76 per cent and 13.75 per cent of them were having marginal size of land holding and land less beneficiaries respectively. 3.33 per cent medium size of land holding i.e. 4.01 to 10 ha and none of them were belongs from big size of land holding category. It was observed from below table that, most of the MGNREGA beneficiaries were having small size of land holding i.e. 1.01 to 2.00 ha.

\section{Occupation}

It was observed from Table 6 that, majority (56.67\%) of the MGNREGA beneficiaries had farming as their main occupation, followed by 30.00 per cent labourer, 8.75 per cent traditional occupation, 4.58 per cent business and none of the beneficiaries belonged to the service. It was observed from below table that, most of the MGNREGA beneficiaries were having farming as main occupation.

\section{Annual income}

It was observed from Table 7 that, more than half $(53.75 \%)$ of the MGNREGA beneficiaries had medium annual income i.e. (Rs.23017 to Rs. 51441), followed by 40.84 per cent of them were belonged from high annual income i.e. (Rs. 51442 and above) and 5.41 per cent of them were belonged from low annual income i.e. (Up to Rs. 23016) category. It was observed from above table that, most of the MGNREGA beneficiaries were having medium annual income i.e. Rs. 23,017 to Rs. 51,441 . 


\section{Family type}

From the Table 8 it can be revealed that, 57.09 per cent of beneficiaries of MGNREGA were live in joint family and (42.91\%) live in nuclear type of family.

\section{Social participation}

It was observed from Table 9 that, near about half $(49.17 \%)$ of the beneficiaries had medium social participation, followed by 27.91 per cent of them had low social participation and remaining 22.92 per cent of them had high social participation. It was observed from below table that, most of the MGNREGA beneficiaries were having medium social participation.

\section{Source of information}

It was observed from Table 10 that, near about half $(46.66 \%)$ of the beneficiaries had medium level of sources of information. Whereas, 33.75 per cent and 19.59 per cent of them were categorized under low level and high level category of sources of information, respectively. It was observed from below table that, most of the MGNREGA beneficiaries were having medium sources of information.

\section{Extension contact}

It was observed from Table 11 that, more than half (59.58\%) of MGNREGA beneficiaries were having medium level of extension contact. While 24.58 per cent and 15.84 per cent of them were having low and high level of extension contact. It was observed from below table that, most of the MGNREGA beneficiaries were having medium extension contact.

\section{Economic motivation}

It is revealed from Table 12 that, less than half $(45.41 \%)$ of the MGNREGA beneficiaries were having medium economic motivation. While, nearly one third (30.83\%) and 23.76 per cent of them had low and high economic motivation, respectively. It was observed from below table that, most of the MGNREGA beneficiaries were having medium economic motivation, followed by low and high respectively.

Table.1 Distribution of the MGNREGA beneficiaries according to their age

\begin{tabular}{|c|c|c|c|c|}
\hline Sr. No. & Category & Age & \multicolumn{2}{|c|}{ Beneficiaries (n=240) } \\
\hline $\mathbf{1 .}$ & Young & Up to 35 years & 84 & Frequency \\
\hline $\mathbf{2 .}$ & Middle & 36 to 50 years & 125 & 52.00 \\
\hline 3. & Old & 51 and above years & 31 & 12.92 \\
\hline & \multicolumn{2}{|c|}{ Mean $\mathbf{4 0 . 7 3}$} & & S.D. $=\mathbf{9 . 4 6}$ \\
\hline
\end{tabular}


Table.2 Distribution of the MGNREGA beneficiaries according to their education

\begin{tabular}{|c|c|c|c|c|}
\hline Sr. No. & Category & & \multicolumn{2}{|c|}{ Beneficiaries (n=240) } \\
\cline { 3 - 4 } & & Score & Frequency & Percentage \\
\hline $\mathbf{1 .}$ & Illiterate & 1 & 21 & 08.75 \\
\hline $\mathbf{2 .}$ & Can read only & 2 & 38 & 15.84 \\
\hline $\mathbf{3 .}$ & Can read and write & 3 & 51 & 21.25 \\
\hline $\mathbf{4 .}$ & Primary school $\left(1^{\text {st }}\right.$ to $4^{\text {th }}$ standard) & 4 & 69 & 28.75 \\
\hline $\mathbf{5 .}$ & Middle school $\left(5^{\text {th }}\right.$ to $7^{\text {th }}$ standard) & 5 & 49 & 20.41 \\
\hline $\mathbf{6 .}$ & High school $\left(8^{\text {th }}\right.$ to $10^{\text {th }}$ standard $)$ & 6 & 12 & 5.00 \\
\hline $\mathbf{7 .}$ & College level & 7 & 00 & 0.00 \\
\hline
\end{tabular}

Table.3 Distribution of the MGNREGA beneficiaries according to their category

\begin{tabular}{|c|c|c|c|}
\hline Sr. No & Caste & \multicolumn{2}{|c|}{ Beneficiaries (n=240) } \\
\cline { 3 - 4 } & & Number & Percentage \\
\hline 1. & Lower Caste ( SC,ST,NT) & 98 & 40.84 \\
\hline 2. & Middle Caste (OBC, MUSLIM) & 75 & 31.25 \\
\hline 3. & Upper Caste (OPEN) & 67 & 27.91 \\
\hline
\end{tabular}

Table.4 Distribution of the MGNREGA beneficiaries according to their family size

\begin{tabular}{|c|c|c|c|c|}
\hline Sr. No. & Category & Score & \multicolumn{2}{|c|}{ Beneficiaries $(\mathbf{n}=\mathbf{2 4 0})$} \\
\cline { 3 - 5 } & & & Frequency & Percentage \\
\hline 1. & Small & Up to 4 members & 38 & 15.83 \\
\hline 2. & Medium & 5 to 6 members & 159 & 66.25 \\
\hline 3. & Big & 7 \& above members & 43 & 17.92 \\
\hline & Mean $=\mathbf{5 . 3 7}$ & & S.D.= 1.60 \\
\hline
\end{tabular}

Table.5 Distribution of the MGNREGA beneficiaries according to their land holding

\begin{tabular}{|c|c|c|c|c|}
\hline Sr. No. & Category & Score & \multicolumn{2}{|c|}{ Beneficiaries (n=240) } \\
\cline { 3 - 4 } & & & Frequency & Percentage \\
\hline 1. & Land less & No land & 33 & 13.75 \\
\hline 1. & Marginal & Up to 1 ha. & 57 & 23.76 \\
\hline 2. & Small & 1.01 to 2.00 ha. & 82 & 34.16 \\
\hline 3. & Semi-medium & 2.01 to 4.00 ha. & 60 & 25.00 \\
\hline 4. & Medium & 4.01 to 10.00 ha. & 08 & 3.33 \\
\hline 5. & Big & 10.01 ha. and above & 00 & 0.00 \\
\hline
\end{tabular}


Table.6 Distribution of the MGNREGA beneficiaries according to their occupation

\begin{tabular}{|c|c|c|c|}
\hline Sr. No. & Category & \multicolumn{2}{|c|}{ Beneficiaries $(\mathbf{n}=\mathbf{2 4 0})$} \\
\cline { 3 - 4 } & & Frequency & Percentage \\
\hline $\mathbf{1 .}$ & Labourer & 72 & 30.00 \\
\hline $\mathbf{2 .}$ & Traditional occupation & 21 & 08.75 \\
\hline $\mathbf{3 .}$ & Business & 11 & 04.58 \\
\hline $\mathbf{4 .}$ & Farming & 136 & 56.67 \\
\hline $\mathbf{5 .}$ & Service & 00 & 00.00 \\
\hline
\end{tabular}

Table.7 Distribution of the MGNREGA beneficiaries according to their annual income

\begin{tabular}{|c|c|c|c|c|}
\hline Sr. No. & Category & Score & \multicolumn{2}{c|}{ Beneficiaries (n=240) } \\
\cline { 3 - 5 } & & & Frequency & Percentage \\
\hline 1. & Low & Up to Rs. 23,016 & 13 & 05.41 \\
\hline $\mathbf{2 .}$ & Medium & Rs. 23,017 to Rs. 51,441 & 129 & 53.75 \\
\hline 3. & High & Rs. 51,442 \& above & 98 & 40.84 \\
\hline \multicolumn{2}{|c|}{ Mean $=\mathbf{5 1 4 4 1 . 6 6}$} & \multicolumn{2}{c|}{ S.D. $=\mathbf{2 8 4 2 5 . 5 7}$} \\
\hline
\end{tabular}

Table.8 Distribution of the MGNREGA beneficiaries according to their family type

\begin{tabular}{|c|c|c|c|}
\hline \multirow{2}{*}{ Sr. No } & Type of family & \multicolumn{2}{|c|}{ Beneficiaries (n=240) } \\
\cline { 3 - 4 } & & Number & Percentage \\
\hline 1. & Nuclear family & 103 & 42.91 \\
\hline $\mathbf{2 .}$ & Joint family & 137 & 57.09 \\
\hline
\end{tabular}

Table.9 Distribution of the MGNREGA beneficiaries according to their social Participation

\begin{tabular}{|c|c|c|c|c|}
\hline Sr. No. & Category & Score & \multicolumn{2}{|c|}{ Beneficiaries (n=240) } \\
\cline { 3 - 5 } & & & Frequency & Percentage \\
\hline $\mathbf{1 .}$ & Low & Up to 2 & 67 & 27.91 \\
\hline $\mathbf{2 .}$ & Medium & 3 to 5 & 118 & 49.17 \\
\hline $\mathbf{3 .}$ & High & 6 \& above & 55 & 22.92 \\
\hline & Mean $=\mathbf{4 . 6 7}$ & & \multicolumn{3}{c|}{ S.D. $=\mathbf{2 . 4 2}$} \\
\hline
\end{tabular}

Table.10 Distribution of the MGNREGA beneficiaries according to their source of Information

\begin{tabular}{|c|c|c|c|c|}
\hline Sr. No. & Category & \multirow{2}{*}{ Score } & \multicolumn{2}{|c|}{ Beneficiaries $(\mathbf{n}=\mathbf{2 4 0})$} \\
\cline { 3 - 5 } & & & Frequency & Percentage \\
\hline 1. & Low & Up to 65 & 81 & 33.75 \\
\hline $\mathbf{2 .}$ & Medium & 66 to 84 & 47 & 46.66 \\
\hline $\mathbf{3 .}$ & High & 85 \& above & & 19.59 \\
\hline & Mean $=\mathbf{8 3 . 7 3}$ & & & S.D. $=\mathbf{1 9 . 2 2}$ \\
\hline
\end{tabular}


Table.11 Distribution of the MGNREGA beneficiaries according to their impact of MGNREGA on occupational change

\begin{tabular}{|c|c|c|c|c|}
\hline Sr. No. & Category & \multirow{2}{*}{ Score } & \multicolumn{2}{|c|}{ Beneficiaries (n=240) } \\
\cline { 3 - 5 } & & & Number & Percentage \\
\hline 1. & Low & Up to 1 & 21 & 08.75 \\
\hline 2. & Medium & 2 to 3 & 165 & 68.75 \\
\hline 3. & High & 4 \& above & 54 & 22.50 \\
\hline \multicolumn{2}{r}{} & & & S.D. $=\mathbf{1 . 9 4}$ \\
\hline
\end{tabular}

Table.12 Distribution of the MGNREGA beneficiaries according to their economic Motivation

\begin{tabular}{|c|c|c|c|c|}
\hline Sr. No. & Category & Score & \multicolumn{2}{|c|}{ Beneficiaries $(\mathbf{n}=\mathbf{2 4 0})$} \\
\cline { 3 - 5 } & & & Frequency & Percentage \\
\hline 1. & Low & Up to 8 & 74 & 30.83 \\
\hline 2. & Medium & 9 to 10 & 57 & 45.41 \\
\hline 3. & High & 11 \& above & \multicolumn{2}{c|}{ S.D. $=\mathbf{2 . 5 2}$} \\
\hline \multicolumn{2}{r}{} \\
\cline { 2 - 5 }
\end{tabular}

Majority $(52.08 \%)$ of the MGNREGA beneficiaries were middle aged, 28.75 per cent educated up to primary school level, $(40.84 \%)$ were found lower category, more than two third $(66.25 \%)$ of them having medium family size and 34.16 per cent of them having small size of land holding. It was observed that, more than half $(56.67 \%)$ of them having farming as main occupation, majority $(53.75 \%)$ of them having medium annual income, 57.09 per cent were found joint family, nearly half $(49.17 \%)$ of them having medium social participation, less than half $(46.66 \%)$ of them having medium source of information, 59.58 per cent of them having medium level of extension contact and 45.41 per cent of them having medium level of economic motivation.

\section{References}

Bhandari, S.D. (2014). Socio-economic impact of Mahatma Gandhi national rural employment guarantee act on the beneficiaries. M.Sc. (Agri.) Thesis, Vasantrao Naik Marathwada Krishi
Vidyapeeth, Parbhani (Maharashtra).

Bhosale, J.S. (2014). Impact of integrated pest management technology in cotton on beneficiary farmers of farmers field school. M.Sc. (Agri.) Thesis, Dr. Panjabrao Deshmukh Krishi Vidypeeth, Akola (Maharashtra).

Garg, S.K., S.K. Badodiya, O.P. Daipuriya and Rawat, U. (2012). Impact of Swarnjayanti Gram Swarozgar Yojna on poverty alleviation in Morar block of Gwalior district. Indian Research Journal of Extension Education (I), pp: 189-191.

Khalache, P.G. and Gaikwad, J.H. (2011). Impact of watershed development programme of watershed organization trust (WOTR) on the beneficiaries in Ahmednagar district. Indian Journal of Extension Education (47), No. 3 \& 4, pp: 104-108.

Khandave, S.R. and Suryawanshi P.S. (2015). Impact of National Horticulture Mission on beneficiaries. J. Agric. Res. Technol. 40 (2), pp: 348-350.

Mankar, D.M., P.P. Wankhade and 
Shambharkar, Y.B. (2013). Impact of National Horticulture Mission on its beneficiaries. International Journal of Exten. Edu. (9), pp: 72-80.
N.M. (2014). Socio-economic impact of improved Soybean technology on farmers. International J. Exten. Edu. (10), pp: 146-152.

Mankar, D.M., P.P. Wankhade and Kale,

\section{How to cite this article:}

Dhulgand, V. G. and Kadam, R. P. 2019. Estimating Profile of the Beneficiaries of Mahatma Gandhi National Rural Employment Guarantee Act. Int.J.Curr.Microbiol.App.Sci. 8(12): 18001807. doi: https://doi.org/10.20546/ijcmas.2019.812.216 